\title{
216. Unstable Multilunar Modifying Genes in the Silkworm, Bombyx mori.*) I
}

\author{
By Yoshimaro TANAKA, M.J.A. \\ National Institute of Genetics, Misima, Sizuoka-ken
}

(Comm. Dec. 12, 1967)

Introduction. Since about twenty years ago, I had a special interest in unstable genes of the silkworm and I accumulated the pertinent experimental data, collecting, on the other hand, the literature on this subject. So far as I am aware, the definition of genetic instability has not yet been settled, and many cases of various kinds have been treated under this name, the observed organisms covering a wide range from higher animals and plants to micro-organisms. Though the classification of all known cases according to the causes of instability is difficult, they may be roughly divided into the following five groups: a) genic, b) chromosomal, c) cytoplasmic, d) developmental, and e) physiological.

The results of Lilienfeld (1929), Demerec (1932), Imai (1934), Malinowski (1935), Sirks (1950), Tanaka (1951, 1954, 1959, 1961, 1962), Lindegren (1953, 1956), Hazelwood et al. (1955), Shifriss (1955), Brink (1956, 1958), Zamenhof et al. (1956, $1958 \mathrm{a}, \mathrm{b}, \mathrm{c})$, Ishikawa (1957), Smith et al. (1957), Sand (1957), Sand et al. (1960), Lewis (1958), Schwarts (1958, 1960), Moav et al. (1960), Sand (1957), Sand et al. (1960), Sandler et al. (1960), Moav (1961), Nagai (1962), Babos et al. (1962), Scholtissek (1962), Barnett et al. (1963), Dawson (1964), Frydenberg (1964), Grigg (1965), Alderson (1966), Alderson et al. (1966), Darlington (1966), Nasim (1966), Ryasty (1966), and Fincham et al. (1967) seem to be due to genic instability.

Some are more related to chromosomal instability as shown by McClintock (1953), Watanabe (1954), Hinton (1955), Snoad (1955), Britton et al. (1956), Frost et al. (1959), Smartt (1960), Murray et al. (1964), Ball (1966), Croft (1966a, b), Hughes et al. (1966), Judd (1967), Morse (1967), and Newmeyer et al. (1967). Ephrussi (1951) reported a cytoplasmic effect on the unstable state of the yeast cell. Developmental instabilities have been observed by Bankowska (1956) and Sakai et al. (1965a, b). The cases of Schaffner (1937), Avi-Dor (1953) and Shifriss (1956) may be classified as at least partly physiological.

*) Contribution from the Silk Science Research Institute, Hyakunin-machi, Shinjuku, Tokyo. 
Notwithstanding that genetic instability covers heterogeneous cases as to their nature, they seem to imply many important problems on the structure and action of genes in higher as well as in microbial organisms.

Materials. Our multilunar strains come from two sources, one was the material sent by Dr. S. Ishiwata of Kyoto Sericultural College in 1915, while the other material was given by Mr. D. Kasai, Director of Fukushima Branch, National Sericultural Experiment Station, in 1917. Both materials are of Chinese origin. Since then, they have been continuously bred in the author's laboratory, and have given rise to various strains by selection.

Characteristics of the marking. The multilunar marking consists of a number of more or less brownish, somewhat rounded spots on the dorsal side of the larva. The spots are present on $3 \mathrm{rd}$, 5th, and 8th segments ${ }^{1)}$ without exception, being superposed upon the "eye-spot" in the 2nd segment. Various multilunar types are distinguished by the number and distribution of spots on 4th, 6 th, 7 th, 9th, and 10th segments.

The multilunar marking develops only when $+^{p}$ gene (normal marking) co-exists with $L$, the major gene for this character. When the larva is homozygous for $p$ (no-marking or plain) instead of $+^{p}$, the marking shows only a faint trace of the characteristic spots which is hardly perceptible even for skilled eyes.

Symbols. In the description of multilunar types, 2nd, 3rd, 5th, and 8th segments can be excluded because they exhibit the spots without exception, but the spots are always absent on the 1st segment. Thus, a type furnished with spots on all abdominal segments is denoted by $\mathrm{L}_{467910}$ and a type in which the spots are absent from all abdominal segments, except 5th and 8th, by $\mathrm{L}_{0}$, and so on.

The spots are usually paired on both sides of the dorsal median line, but they are not unfrequently single. If special exactitude is needed, we represent an unpaired spot by putting a dot upon the segment number, for instance, $\mathrm{L}_{467910}$. In most cases, however, paired and unpaired spots are not distinguished from each other and only the segment numbers where the spots occur are given.

I have assumed two groups of multilunar modifiers: L-developing and L-inhibiting modifiers. L-developing modifiers are indicated by $D_{4}, D_{6}, D_{7}$, etc. and L-inhibiting modifiers by $I_{4}, I_{6}, I_{7}$, etc. The method of testing modifier constitutions will be mentioned later.

1) Larval segments of the silkworm are, for the sake of simplicity, counted from the 1st thoracic segment down to the 7 th abdominal segment. The 1st abdominal segment is our 4th segment, and our 10th segment means 7 th abdominal segment. 


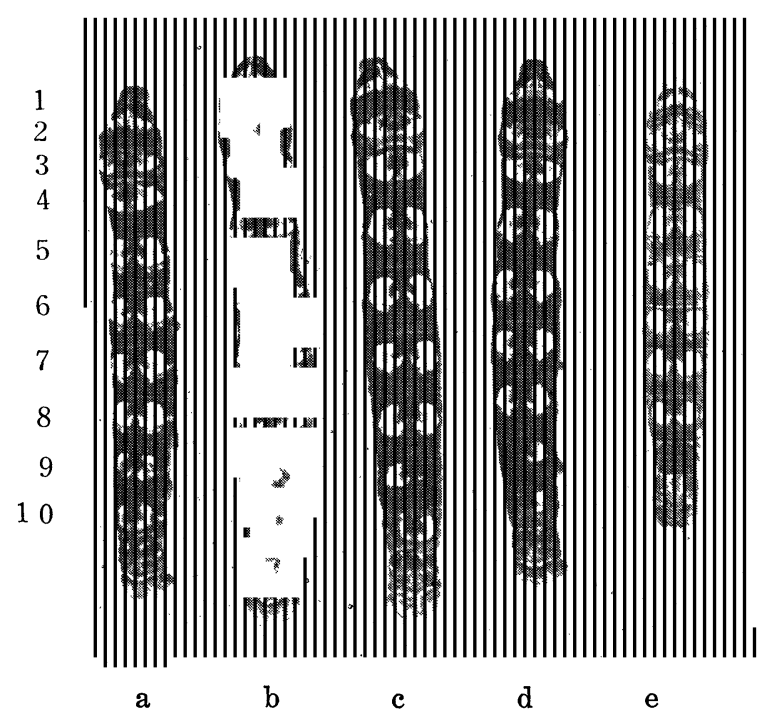

Fig. 1. Several multilunar types (1)

$\begin{array}{lllll}\text { a) } \mathrm{L}_{167910} & \text { b) } \mathrm{L}_{4679 i_{0}} & \text { c) } \mathrm{L}_{467910} & \text { d) } \mathrm{L}_{167910} & \text { e) } \mathrm{L}_{4679}\end{array}$

Numerals on the left represent segment numbers.

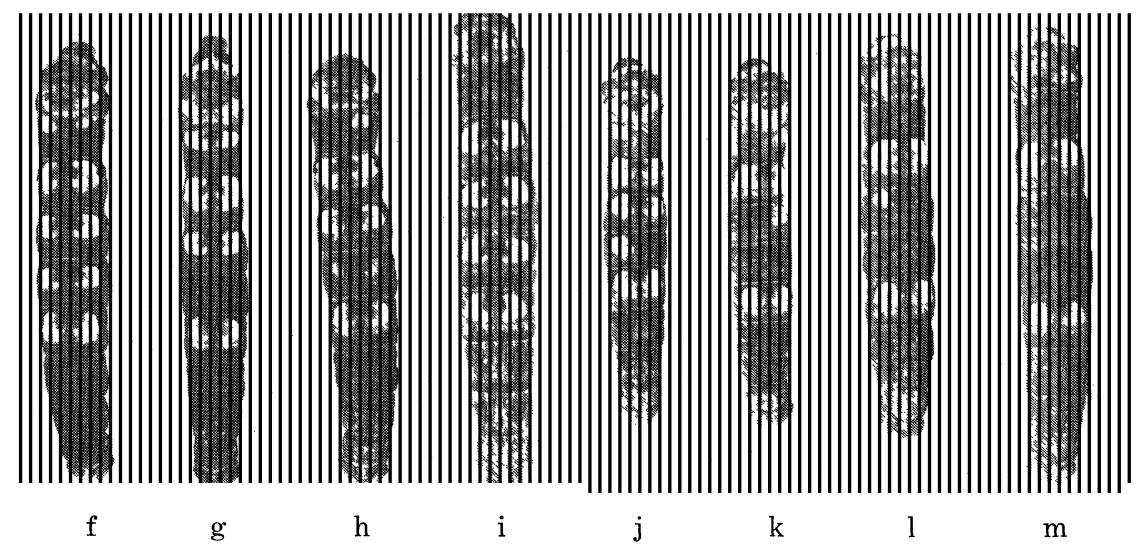

Fig. 2. Several multilunar types (2)

$\begin{array}{llllllll}\text { f) } \mathrm{L}_{467} & \text { g) } \mathrm{L}_{46} & \text { h) } \mathrm{L}_{467} & \text { i) } \mathrm{L}_{67} & \text { j) } \mathrm{L}_{467} & \text { k) } \mathrm{L}_{46} & \text { l) } \mathrm{L}_{6} & \text { m) } \mathrm{L}_{0}\end{array}$

Stability of the major gene. The multilunar marking is a product of the major gene $L$ and a number of modifiers. In contrast to very unstable L-modifiers, the major gene $L$ is perfectly stable. During fifty years of rearing, I have observed more than hundred generations of multilunar strains, but have never met either with spontaneous or induced mutations of $L$, while rather frequent mutations have been found in other larval markings such as normal $\left(+^{p}\right)$, moricaud $\left(p^{M}\right)$, striped $\left(p^{S}\right)$, zebra $(Z e)$, and so on.

Instability of L-modifiers. In order to avoid the deleterious 
effects of strict inbreeding in the silkworm, we preferred a method of moderate inbreeding for the maintenance of various strains as follows: Different multilunar types in a culture (lot) are separated, counted and recorded. The standard type of the strain is selected, and mated inter se to obtain several batches of eggs. Some three batches are taken and each batch is cut into three pieces. The larvae hatched from three one-third pieces of the batches are mixed together and reared together in the same lot. This process is repeated in each generation. Table I shows the results for the latest ten generations of several strains.

The table clearly shows that stability widely varies by the strain. $\mathrm{L}_{467910}$ is perfectly stable, while $\mathrm{L}_{0}$ comes next, proving that there is no positive relation between number of spots and stability.

Table I. Actual numbers and percentages of standard types in latest ten generations of various strains

\begin{tabular}{|c|c|c|c|c|c|c|c|c|}
\hline tyr & $\mathrm{L}_{0}$ & $\mathrm{~L}_{6}$ & $\mathrm{~L}_{46}$ & $\mathrm{~L}_{67}$ & $\mathrm{~L}_{467}$ & $\mathrm{~L}_{4679}$ & 10 & 146 \\
\hline Str & $l 6$ & $l 5$ & & $l 54$ & $l 1$ & & & \\
\hline & & $\%$ & & & & & no. & \\
\hline 1 & $\frac{329}{334} 98.5$ & $\frac{171}{258} 66.3$ & $\begin{array}{cc}43 & 13.6 \\
316 & \end{array}$ & $\frac{152}{211} 72.0$ & $\begin{array}{l}123 \\
327\end{array} 37.6$ & $\frac{291}{368} 79.1$ & $\frac{105}{489} 21.5$ & 2966 \\
\hline 2 & $\frac{270}{295} 91.5$ & $\frac{298}{328} 90.9$ & $\frac{173}{422} 41.0$ & $\frac{122}{132} 92.4$ & $\frac{154}{227} 67.8$ & $\frac{84}{264} 31.8$ & $\begin{array}{cc}52 \\
358 & 14.5\end{array}$ & $\frac{290}{290}$ \\
\hline 3 & $\frac{290}{292} 99.3$ & $\frac{146}{260} 56.2$ & $\frac{104}{264} 39.4$ & $\frac{336}{349} 96.3$ & $\frac{170}{173} 98.3$ & $\frac{189}{235} 80.4$ & $\frac{73}{362} 20.2$ & $\frac{352}{352} 1$ \\
\hline 4 & $\frac{269}{305} 88.2$ & $\begin{array}{l}293 \\
376\end{array} 77.9$ & $\frac{110}{247} 44.5$ & $\frac{133}{136} 97.8$ & $\frac{107}{141} 75.9$ & $\frac{196}{301} 65.1$ & $\frac{50}{461} 10.9$ & 450 \\
\hline 5 & $\frac{329}{347} 94.8$ & $\frac{36}{258} 1$ & $\frac{21}{269} \quad 7.8$ & $\frac{227}{233} 97.4$ & $\frac{239}{246} 97.2$ & $\begin{array}{cc}33 & 9.2 \\
359 & 9.2\end{array}$ & $\frac{95}{382} 24.9$ & \\
\hline 6 & $\frac{45}{50} 90.0$ & $\frac{55}{102} 53.9$ & $\frac{65}{309} 21.0$ & $\frac{164}{280} 58.6$ & $\frac{170}{180} 94.4$ & $\frac{111}{175} 6$ & $\begin{array}{c}27 \\
363\end{array}$ & 336 \\
\hline 7 & $\frac{411}{416} 98.8$ & $\frac{157}{266} 59.0$ & $\frac{104}{251} 41.4$ & $\frac{181}{248} 73.0$ & $\frac{110}{119} 92.4$ & $\begin{array}{ll}236 & 88.7 \\
266 & \end{array}$ & $\frac{19}{235}$ & 434 \\
\hline 8 & $\frac{355}{421} 84.3$ & $\frac{162}{266} 60.9$ & $\frac{82}{307} 26.7$ & $\frac{142}{300} 47.3$ & $\begin{array}{l}222 \\
237\end{array} 93.7$ & 32689.8 & $\frac{51}{345} 14.8$ & 107 \\
\hline 9 & $\frac{234}{287} 81.5$ & $\frac{119}{165} 72.1$ & $\frac{184}{259} 71.0$ & $\frac{202}{256} 78.9$ & $\frac{304}{328} 92.7$ & $\frac{437}{498} 87.8$ & $\frac{40}{212} 18.9$ & 417 \\
\hline 10 & $\frac{175}{180} 97.2$ & $\frac{34}{78} 43.6$ & $\begin{array}{ll}237 & 67.7 \\
350 & \end{array}$ & $\frac{139}{140} 99.3$ & $\begin{array}{l}220 \\
223\end{array} 98.7$ & 113985.6 & $\begin{array}{cc}\frac{79}{481} & 16.4\end{array}$ & 344 \\
\hline & & 59.5 & 37.4 & & 84 & 68.1 & 15.7 & 100 \\
\hline & & 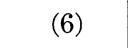 & (7) & & & & (8) & (1) \\
\hline
\end{tabular}

The numerator of fraction shows the actual number of standard type larvae and the denominator shows the total number of larvae in the same lot.

The percentages indicate the degree of stability of each strain. "Order" means the order of stability, from higher to lower, the order of instability is naturally just reversed. 
Stability depends, it seems to me, upon the degree of balance of the acting various multilunar modifier genes. $\mathrm{L}_{467910}$ involves the maximum number of L-developing modifiers, but has no L-inhibiting modifiers. It is perfectly homogeneous so far as to modifiers are concerned. All L-developing modifiers act in the same direction, and perhaps are firmly united together. $\mathrm{L}_{0}$ is thoroughly free of L-developing modifiers, but it may or may not involve some L-inhibiting modifiers such as $I_{9}$ and $I_{10}$, as was proved by gene analysis, though they cannot be phenotypically distinguished. It is somewhat heterogeneous. This seems to account for the fact that $\mathrm{L}_{0}$ takes second place to $\mathrm{L}_{467910}$ in stability. Other multilunar types are mixtures of various modifiers, or much more heterogeneous of them, whence come their instabilities.

\section{References}

Alderson, T. (1966): Heredity, 21, 528.

Alderson, T., and Khan, A. H. (1966): Heredity, 21, 530.

Avi-Dor, Y., and Yaniv, H. (1953): J. Bacteriol., 66, 1-5.

Babos, P., and Kassanis, B. (1962): Virology, 18, 206-211.

Ball, C. (1966): Heredity, 21, 531.

Bankowska, H. (1956): Acta Agrobotanica, 5, 71-137 (in Russian).

Barnett, E., and Serres, F. J. de (1963): Genetics, 48, 717-723.

Brink, R. A. (1956): Genetics, 41, 872-889.

- (1958): Genetics, 43, 435-447.

Britton, D. M., and Hull, J. W. (1956): J. Heredity, 45, 205-210.

Callo, V., Olivares, J., and Montoya, E. (1963): Science, 142, 1668-1669.

Croft, J. H. (1966a): Heredity, 21, 528-529.

- (1966b): Heredity, 21, 565-579.

Darlington, O. (1966): Heredity, 21, 527-528.

Dawson, G. W. P. (1964): Genet. Res. Camb., 5, 423-431.

Demerec, M. (1932): Proc. 6. Intern. Congr. Genet. II, 43.

Ephrussi, B., and Hottinguer, H. (1951): Cold Spring Symp. Quant. Biol., 16, 75-85.

Fincham, J. R. S., and Harrison, B. J. (1967): Heredity, 22, 211-224.

Frost, H. B., Lesley, M. M., and Locke, W. F. (1959): Genetics, 44, 1083-1099. Frydenberg, O. (1964): Hereditas, 51, 198-206.

Grigg, G. W. (1965): Heredity, 20, 138-141.

Hagemann, R. (1958): Z. Abstammungslehre, 89, 587-613.

Hazelwood, A., and Gorton, E. (1955): Bull. Brit. Ornithol. Club, 75, 94-95.

Hinton, C. W. (1955): Genetics, 40, 951-961.

Hughes, D. T., and Austin, S. (1966): Heredity, 21, 531-532.

Imai, Y. (1934): Japan. J. Genet., 10, 89-90.

Ishikawa, T. (1957): Japan. J. Genet., 32, 213-222.

Judd, B. H. (1967): Genetics, 56, 569.

Lewis, C. F. (1958): J. Heredity, 49, 267-271.

Lilienfeld, F. A. (1929): Bibliotheca Genet., 13, 1-124.

Lindegren, C. C. (1953): J. Genet., 51, 625-637.

- (1956): Science, 124, 26-27. 
Mc Clintock, B. (1953): Genetics, 38, 579-599.

Malinowski, E. (1935): Genetics, 20, 342-356.

Moav, R., and Cameron, D. R. (1960): Amer. J. Bot., 47, 87-93.

Moav, R. (1961): Genetics, 46, 1069-1087.

Morse, M. L. (1967): Genetics, 56, 331-351.

Murray, B. E., and Claig, I. L. (1964): Canad. J. Genet. Cytol., 6, 170-177.

Nagai, S. (1962): Exp. Cell Res., 26, 253-259.

Nasim, M. A. (1966): Heredity, 21, 528.

Newmeyer, D., and Taylor, C. W. (1967): Genetics, 56, 771-791.

Nga, B. H., and Roper, J. A. (1966): Heredity, 21, 530-531.

Ryasaty, S. (1966): Heredity, 21, 528.

Sakai, K., and Shimamoto, Y. (1965a): Genet. Res. Camb., 6, 93-103.

(1965b): Genetics, 51, 801-813.

Sand, S. A. (1957): Genetics, 42, 685-703.

Sand, S. A., Sparrow, A. H., and Smith, H. H. (1960): Genetics, 45, 289-308.

Sandler, L., and Hiraizumi, Y. (1960): Genetics, 45, 1269-1287.

Schaffner, J. H. (1937): J. Heredity, 28, 426-427.

Scholtissek, C. (1962): Nature, 194, 353-355.

Schwartz, D. (1958): Genetics, 43, 86-91.

- (1960): Genetics, 45, 1141-1152.

Shifriss, O. (1955): J. Heredity, 46, 213-222.

- (1956): Genetics, 41, 265-280.

Sirks, M. J. (1950): Genetica Iberica, 2, 109-111.

Smartt, J. (1960): Nature, 186, 1070-1071.

Smith, H. H., and Sand, S. A. (1957): Genetics, 42, 560-582.

Snoad, B. (1955): Heredity, 9, 129-134.

Srb, A. M. (1958): Heredity, 12, 237-270.

Tanaka, Y. (1951): Ann. Rept. Natl. Inst. Genet. Japan, 1, 10-14.

- (1954): Lect. Tokai Branch, Seric. Soc. Japan, 2, 29-35.

- (1959): Rept. Silk Sci. Res. Inst. Japan, 7, 36-42 (in Japanese).

- (1961): Rept. Silk Sci. Res. Inst. Japan, 9, 17-29 (in Japanese).

- (1962): Rept. Silk Sci. Res. Inst. Japan, 10, 1-12 (in Japanese).

Watanabe, Y. (1954): Japan. J. Breeding, 4, 67-76.

Zamenhof, S., Leidy, G., Hahn, E., and Alexander, H. E. (1956): J. Bacteriol., $\mathbf{7 2}, 1-11$.

Zamenhof, S., Greer, S., and Giovanni, R. de (1958a): J. Bacteriol., 75, 510-513. Zamenhof, S., Giovanni, R. de, and Greer, S. (1958b): Nature, 181, 827-829.

Zamenhof, S., and Greer, S. (1958c): Nature, 182, 611-613. 